\title{
Cultures of (dis)trust: Shame and solidarity from recipient NGO perspectives
}

\section{Beata Paragi}

Corvinus University of Budapest, Hungary

\begin{abstract}
The article is concerned with the perceptions and experiences of civil society actors receiving foreign aid from international and regional donors. By means of qualitative data analysis and within the analytical framework of gift exchange it aims to explore the 'spiritual essence' of contemporary gifts. Findings draw attention both to conflict and cooperation entailed by external gifts in light of the multiple understandings of culture.
\end{abstract}

\section{Keywords}

adaptation to the environment, civil society, culture, development cooperation and communication, foreign aid, gift, humanitarian aid, NGO, Palestine, shame/stigma

Foreign aid aspires to achieve global solidarity within the international community (Salamon, 2015; Wilde, 2013). ${ }^{1}$ This modern gift (Baldwin, 1985; Eyben, 2006; Furia, 2015; Hattori, 2001; Kapoor, 2008) attempts to connect culturally, economically and politically distinct worlds; this is not without its controversies though. Modern gift-giving is one of the most influential ways of managing order and preventing violence (Duffield, 2001, 2007; Furia 2015; Hénaff, 2010; Komter, 2005; Pyyhtinen, 2014). At the international level, it is conditional on the active participation and cooperation of non-governmental organizations (NGOs) and the media (Chouliaraki, 2013; Duffield, 2007). Contrary to the public discourse on the noble goals of development and humanitarian assistance,

\section{Corresponding author:}

Beata Paragi, Corvinus University of Budapest, Fovam ter 8., Budapest, 1093 Hungary.

Email: beata.paragi@uni-corvinus.hu 
contemporary forms of (compassion-based) solidarity with remote others, coupled with efficient communication strategies, may be regarded as a controversial and ironic endeavour, strengthening identities mostly on the donor side (Chouliaraki, 2013; Razack, 2007).

The fact that donors and foreign aid play a role that is as influential as it is ambiguous in Palestine has not only been widely discussed in the literature (Brynen, 2000; Keating, 2005; Le More, 2008; Taghdisi-Rad, 2011) but Palestinian perceptions of donor motives, interests, behaviours and agenda-setting attitudes have also been explored by earlier studies (Paragi, 2016c, forthcoming; Said, 2005; Springer, 2015; Wildeman and Tartir, 2014). This article further explores development cooperation and communication from the 'recipient' perspective at the level of NGOs within the analytical framework offered by gift exchange theories. To capture the perspectives and experiences of the interviewees working with NGOs at the recipient end of the aid relationship, qualitative data were collected and analysed through a grounded theory approach (Glaser and Strauss, 1967), which encouraged me to interpret foreign aid relations within the context of gift exchange both at micro and macro level (following Furia, 2015; Hattori, 2001, 2006; Kapoor, 2008; Mauss, 2000 [1925]; Stirrat and Henkel, 1997).

By applying qualitative methods, this article focuses on the 'spiritual essence' (Mauss, 2002 [1925]), that is, on the culture-related elements mediated by contemporary gifts (foreign grants). Foreign aid, whether it is a macro-level programme, a micro-project, voluntary work or other private charity donation, has the power to influence cultural and political borders by transferring norms and values from the donor to the recipient. While I try not to essentialize culture ${ }^{2}$ by putting the respondents and their responses into 'closed boxes' (in a normative sense, at the level of norms), the reader should also be aware that understanding the speakers' arguments is possible only by taking into consideration our respondents' self-reflection on their cultural and/or religious belonging (in a descriptive sense, at the level of facts). The article is structured as follows: the first section introduces the context and the methods, the second presents the findings, and the third provides room for discussing the results.

\section{Conceptual framework and methods}

\section{Theoretical frames in a nutshell (spiritual essence)}

By focusing on 'what aid does' and interpreting foreign aid (relations) within in the analytical framework of gift exchange (following Mauss, 2002 [1925]; Sahlins, 1972), earlier studies concluded that it aims 'to make international order' by means of 'symbolic domination' (Baldwin, 1985, 1998; Hattori, 2001, 2006; Kapoor, 2008; Furia, 2015). Accepting that the primary purpose of the aid (gift) relationship is to maintain relations between the donor and the recipient, ${ }^{3}$ the relation between them should be scrutinized with extra attention to understand the role played by cultural factors in maintaining this relationship. The gift 'does not affect only isolated and discontinuous incidents in social life but social life in its entirety' (Godbout and Caille, 1998: 11), which simultaneously includes the relations (transactions, social interactions) between actors and the gift-object too. As argued by Olli Pyyhtinen, the gift presents 'how relation is transformed into thing and thing into relation' (2014: 6). The gift - foreign aid 
too - gains its 'meaning, value and force in and through relations' (Pyyhtinen, 2014: 6). Beyond its material properties, the gift bears important information on 'social' properties, such as the giver and the intentions behind their giving, the recipient, and the history and future of the relation between the giver and the recipient, which all determine the meaning of the gift, its dark side included (Pyyhtinen, 2014: 101-8). It is the 'relation' between the donor and the recipient, an essential element of gift-giving, which makes it possible to analyse foreign aid practices within the analytical framework of gift exchange. If 'to accept something from somebody is to accept some part of his spiritual essence, of his soul' (Mauss, 2002 [1925]: 16), this 'some part of his spiritual essence' deserves attention in case of any cross-cultural cooperation. Norms and values, whether they are labelled as western, neoliberal or Islamic, are part of the 'spiritual and material package' received from donors. The article will focus on this 'package'.

Civil society actors (NGOs, grassroots initiatives) contribute a lot to foreign aid implementation worldwide. The role most of them play in providing necessary services to various segments of populations seems to offset the critiques (Anheier, 2014; Uphoff, 1993). However, many of them not only implement 'contemporary' humanitarian and development services and give 'international gifts', but also act as organizational agents, influencing both discourse and actions (Chouliaraki, 2010; Hardy et al., 2000). Since a great part of their resources come from governmental sources, many of them seem to advocate mostly western foreign policies and 'neocolonial' practices (Duffield, 2007; Kothari, 2006; Smillie, 1995). While NGOs and grassroots organizations are widely seen as channels for promoting peace, economic development or providing basic services to the population if the state is weak (Uphoff, 1993), often they simultaneously play a controversial role in implementing official aid policies in the Middle East as well (Carapico, 2014; Nakhleh, 2013; Tabar et al., 2015).

\section{The research context: NGOs in Palestine}

The Palestinian non-governmental sector ${ }^{4}$ is exceptionally vibrant and active, which is due to the unique historical context and the overwhelming donor interests in supporting the Oslo peace process since 1993 (Bouris, 2014; Brynen, 2000; Keating et al., 2005; Le More, 2008; Tabar et al., 2015; Taghdisi-Rad, 2011; Tartir, 2014). It provided various services to the population well before the beginning of the peace process and the establishment of the Palestinian Authority (PNA) in 1994. However, it was the peace process which brought about major changes both in quantitative and qualitative terms. Due to the huge foreign interest in 'supporting the peace process' and the relative abundance of sources, a completely new NGO sector emerged at the expense of the older, indigenous initiatives..$^{5}$ This 'tier' of NGOs was cut off not only from the final beneficiaries that they were supposed to serve, but also from the grassroots organizations and the PNA itself (Dana, 2013; Nabulsi, 2005: 124). The failure of the peace process, the prolonged Israeli occupation and the donor money keeping the PNA alive, presents a huge challenge for the indigenous civil society. While NGOs are supposed to play a significant role not only in implementing projects in the field of development and humanitarian assistance but also in the 'emergence of a democratic system and democratic practices in the West Bank and Gaza Strip', their role and influence has 
been constantly undermined by the PA/PNA, Israel, and in some sense by the donors too (Murad, 2014; Nabulsi, 2005: 122).

\section{Data collection and analysis}

The study was based on desk research and fieldwork. The interviews were conducted in a natural setting - in the West Bank and Gaza Strip (Palestine) - in which the NGO people approached for the study worked. The data collection was part of a larger project tracking the recent changes of western aid policies in Egypt, Jordan and Palestine, and how these changes have been applied to control regional developments; to understand how western aid policies have contributed to the 'Arab Spring' and how the focus of western aid has been changing; and, finally, to understand local perceptions on aidrelated foreign interventions. Aspects of the broader context were reported elsewhere (Paragi, 2015, 2016a, 2016b). The most recent - and from the perspective of this article the most relevant - round of interviews was conducted in the West Bank and Gaza Strip from July to September 2015. The interviews aimed to explore at a personal level the feelings and human experiences attached to or stemming from daily interactions between organizations (between the NGO recipient and the donor organization). ${ }^{6}$ The data offered a much broader pool of findings that can be presented and discussed here, so only those reflecting on the culture-related dimensions of cooperation will be described and discussed in this article.

The data analysis resulted in conceptualizing latent patterns and structures of international development cooperation - as perceived and experienced by recipient NGOs - by means of the process of constant comparison ${ }^{7}$ (Corbin and Strauss, 1998). First, by reading the transcripts, line-by-line coding was performed with the aim of identifying basic elements (codes) labelled, for example, as 'like-mindedness', 'Christian (church) values', 'Islamic charity', 'leftist ideas', 'shame', 'credibility and transparency', 'normalization with Israel' and a lot else. The second step was about identifying connections between the categories and recognizing sub-dialectics, such as 'western/global/neoliberal vs. national/local' cultures, or 'shared values/ norms vs. shameful cooperation'. Codes related to the cultural dimensions of cooperation were scrutinized with extra attention; for example, 'like-mindedness' was divided into three sub-categories (western, leftist and/or neoliberal; western: churchoriented; Islamic-Arab). In the third step, relations between categories and subdialectics were merged into bigger categories based on their content. For example, the main code 'influencing factors' covered 'time', 'size', 'like-mindedness' and the 'physical presence/closeness of the donor'. Finally, interview excerpts were analysed to understand how culture-related experiences with project implementation from the perspective of the non-governmental recipient relate to the norms conveyed by the aid given.

\section{Findings}

The processed data enabled me to identify the most important concepts and patterns perceived by NGO recipients in an aid relationship, in which the donor could be 
an individual, a local or international NGO or an official partner, a donor agency or an international organization. Our respondents' experiences with their donors reflected the main factors determining successful cooperation: the physical presence/closeness of the donor; time; like-mindedness and the relative size ${ }^{8}$ of the recipient NGO in relation to the donor organizations on the one hand. On the other hand, they illustrated how 'culture' embodied in foreign gifts may simultaneously create bonds and strengthen division lines.

\section{Explanatory factors of successful cooperation}

Summarizing the interviewed NGO leaders' experiences, successful cooperation depended on the quality and intensity of human relations between the individuals representing the concerned organizations. Closeness clearly mattered for ' $[\mathrm{y}] \mathrm{ou}$ need to get involved and work [directly, not from western capitals] with recipients to be able to capture the whole languages and structures that we work through' (WB11). Many donor organizations and people were considered as outsiders both in physical and cultural sense:

They are following up from a desk work in Europe, while they never visited Palestine, so they're not well aware of the Palestinian mentality and social life, making them following the agreed policies and procedures, while being inflexible, not adaptive, and lack of understanding of difficulties facing local humanitarian practitioners on field. (WB12)

Regarding time and the endurance of relationships 'it is good to work with donor's staff for long time', as it was explained by an NGO manager, because 'they understand you and they know more about our society which will help the implementation of projects' (WB8). In other words, the longer the donor and the recipient worked together, the more they knew each other, the more they thought alike in terms of the political context, social and cultural dimensions, the more satisfied our respondents were with the results of the cooperation. The fact that a strong relationship between the donor and recipient (at micro level) may also have a sort of negative impact on the civil society sector was explained this way (WB8):

Close relationships [between the donor and the recipient] are very important. The donors know and seek this. I think a certain level of comfort develops between donors and their partners with whom they have had previous success. This may lead to the exclusion of other local NGOs that may be more worthy.

While the length of cooperation obviously led to familiarity, trust, culture and common values were equally seen as decisive factors for 'like-minded organizations form better alliances' (WB4). Since 'donors seek comfort and certainty' (WB8) they reportedly looked for partners with similar political, social, religious and/or cultural values. Churchrelated western and international NGOs work with Palestinian-Christian organizations since 'they are considered [one] family' (WB2). Others reported receiving 'funding from private sources and "leftist" sources [...] mostly from organizations that are ideologically close to us' (WB9). In similar vein, religious Islamic NGOs receive funding mostly 
from Muslim and Arab states, simply because 'the[ir] culture and traditions are very close to ours' (GS9):

Most of the donor institutions and the charity organizations are from Arab countries, they provide assistance for Gaza and show solidarity with us [...] they help us because it is the duty of them from the perspective of religious and Islamic, where we share the same traditions as Arab and Muslims. [...] many of us [Palestinians] [...] are aware of most of the Arab traditions, most of our donor partners share the values we do, even our political thinking is very similar.

Other responses illustrated the overlapping dimensions of funding priorities, politics and culture: 'Saudi Arabia will never provide funds for a democratic election campaign, simply because the [culture of] democratic election system [is missing] in Saudi Arabia', and, in similar vein, 'Qatar will never support a conference for women or youth rights, because Qatar does not believe in women and youth rights' (GS2). This quote reveals a common dilemma faced by NGO leaders. On the one hand, they prefer working with politically similar and culturally familiar donors simply because like-mindedness makes cooperation easier. On the other hand, the very essence of aid cooperation is to bring about changes in terms of both the humanitarian and development aspects, the overall goal of which would require the actors to overcome their differences.

\section{The 'spiritual essence': managerial skills, cultural values and national aspirations}

Flexibility in using the term 'culture' during the interviews provided an opportunity to learn how respondents themselves reflected on it. While in many cases the obvious line of distinction was set between 'us' (our Palestinian culture, habits, norms, values) and 'them' (western, international donors), aid interactions reportedly led to changes within the recipient both at the level of individual thinking and in organizational terms. Indeed, '[working] with donors, especially foreign ones, changes, at least for a bit, one's values. Perhaps if I didn't do what I do, my reaction to cases of honour violence would be far more sympathetic' (WB5). The leader of an NGO (GS3) working in the field of human rights reported the perceived impact this way:

[B]y the time and through the relation with others, including the donor organization[s], we gain more experience, not only at the professional level, but at social and cultural levels. We learned many values related to the daily social interactions; respect the others, appointments, the principles of human rights, [and] gender equality. [While] all these values can be found in our society we practise these values more [better, more intensively] with our donor partners. We have gained all these things with the passage of time and by the exchange of ideas.

Others reported having learned 'a lot with respect to the administrative subjects, the ways of thinking, the ethics, organization, planning, and work habits' (GS2) and the know-how of 'proposal and report writing' (GS5). These managerial skills and 'modern management methods' apparently contributed a lot to develop a more efficient organizational culture needed to build projects and secure funding from western sources. However, 
many of our respondents complained that 'westerners' are more concerned with procedures than with substance. It 'undermines their [officially stated] goals [regarding peacebuilding and Palestinian self-determination] [since donors] supervise projects that are disconnected from the reality of the beneficiaries' (WS10). Indeed, the bureaucratized, competition-conscious and market-oriented approach in the aid industry, labelled as 'neoliberal', made NGO leaders learn 'how to address the donors with the language that most suits their sensitivities; politically, ideologically and socially; you know the vocabulary to use with [a given] donor' (WB3). Perceptions of donors' 'neoliberal interests' reveal a dual understanding of culture: while it may exist at organizational level (ensuring cooperation between the donor and the recipient), if understood in national terms, it marks a division line between donors' thinking and recipients' national priorities.

The complex understanding of culture and cultural influence reflects on the 'software of mind', expressing the way respondents within the NGO sector think about the role played by various values in their everyday work (Hofstede et al., 2005). Interestingly, western donors' universal humanitarian values were somehow contrasted with the local ones. Our respondents emphasized that 'we still maintain our values obviously, but we learn from their humanitarian dedication' too (WB4) and 'we learned from them [...] how to be more humanitarian' (GS7). Moreover, cooperation with western donors or activists was acknowledged to influence ways of thinking and action both inside and outside of the scope of NGO work. As an NGO adviser elaborated on the positive side of the sub-dialect of cultural change that affected the societal level (WB7):

[I]f we have a look at the voluntary works of some groups who are doing voluntary work in Palestine [against the apartheid wall], we found that they are affecting our people and some of them encouraging the resistance in very positive ways, especially when Palestinians activists found that foreigners participated and joined them in demonstrations against Israeli occupation.

While the role played by foreigners may strengthen solidarity between Palestinians on the one hand and foreign volunteers, activists and donors on the other hand, it also has negative implications at the macro level of politics and sociology. Indeed, on the other side of the same sub-dialect, a project coordinator at another West Bank NGO (WB8) complained about the negative impacts of adapting to 'foreign' values:

We, Palestinians, always consider throwing stones against Israeli soldiers as part of non-violent actions, but some INGOs consider it as violence, so I see these changes [their impact on Palestinian actions] as negative changes. These changes [concerning this part of the national movement, that is, the civil society activism] helped the Israeli occupation [take advantage of] the limits of resistance, so the Israelis managed easily to build the wall.

Other respondents expressed frustration over the fact that 'the [aid] relationships were not long enough to make a real difference in terms of values' (WB7), which confirms the importance of time and the quality of the relationship in successful cooperation. Regarding the nature of relationship, there were respondents who acknowledged the blurred borders between friendship and professional cooperation by emphasizing that 'the partnership is based on confidence and friendly relations, it is not only a relation for 
getting the money' and added that 'we receive them as guests in our homes, and eat lunch or dinner, but they also invited us me when I was in [western country] to their homes' (GS3). There were others emphasizing that it was better to separate them for the sake of professional efficiency:

Most of the relations between us and our donor partners are professional relations, I can't consider this relation as private or friendship relation [...] but our relation with our donors is chummy with high trust and mutual respect. We work together to serve our people. (GS10)

Our respondents emphasized not only the importance of personal-level sympathy and empathy, common vision in politics, shared social and cultural values at the beginning of a relationship, but the instrumental role foreign norms and values play in challenging, changing or preserving cohesion at the level of NGOs and the wider Palestinian society alike.

\section{Shame: a closer look at shared values and the non-material impact on foreign aid}

While most NGO leaders and advisers were generally comfortable with the inherent likemindedness and used it strategically to raise funds and to cultivate effective work relations with funding organizations, a certain tension was also acknowledged either explicitly, or implicitly. The importance of common culture - both in organizational sense and from political, ideological and religious perspectives - was raised during the discussions not only to highlight 'what binds', but also as a force creating division lines and troubling order within (civil) society.

Western donors have tended to exclude a broad range of actors from their 'secular' vision of peacebuilding in Palestine. This practice applies to two somewhat overlapping groups: the majority of religious (Islamist) organizations ${ }^{9}$ and those organizations that did not denounce violence towards Israel. Leaders of Islamic NGOs complained of having been ignored unfairly by western donors, even when they claimed to be well-prepared in terms of organization culture, 'modern management and communication' skills. As argued, western donors should have paid more attention to the professional quality of their work, since their work is defined by commitments to 'professionalism and high transparency' (GS9). They also appealed, though implicitly, to the principles of international humanitarian law to justify why their beneficiaries (injured people, prisoners, wounded) should have been given attention and money regardless of [their Islamic] religion and faith. Nevertheless, they sensed a high level of suspicion surrounding their activities as western donors were reportedly reluctant to support the majority of local Islamic organizations. ${ }^{10}$ A leader of an Islamic NGO (GS10) elaborated on the differences in discourse: ${ }^{11}$

The problem with the European and American donor institutions [is] that they don't deal with us, because they are ashamed to deal with us.[... These donors are boycotting all the Palestinian associations dealing with 'wounded people' and 'prisoners' [...] some of the European donor institutions asked us to change the name of the association and to not mention the word 
'wounded' as a condition to deal with us, other donor institutions asked us to appoint women in the Board of Directors [in exchange] for approval of funding [our organization]. These conditions are either political or whatever, but they are not accepted for us, we can accept [only] advices related to the improvement the quality of the work.

This quote illustrates the power of language determining 'what is true and what is false'. It does not matter 'whether the Palestinians are terrorists or not, if we think they are, and act on that "knowledge," they in effect become terrorists because we treat them as such' (Hall, 1996: 203). Our research was not concerned with hunting for terrorists, but it was obvious that the Palestinian NGOs had to respond to this challenge. US aid to Palestinian NGOs has long been conditional on the so-called 'material support clause' regulations. Examples are the Partner Vetting System and Anti-Terror Certification, both of which aim to ensure the 'clarity' of the local implementing partners (Lazarus and Gawerc, 2015: 68). Accepting aid with inconvenient conditions was perceived as a sort of stigma leading to legitimacy problems within the recipient society and affecting the NGO's ability 'to recruit participants, to build partnerships, and to achieve the impacts envisioned by donors and practitioners alike' (WB12).

Unlike the (suspected) involvement of 'terror-related' figures, cooperation with Israeli partners has been widely advocated by western donors:

Programmes that involve Israeli partners are much easier to fund than any other, regardless of the actual quality of the programmes or even their accountability. [...] Organizations that administer normalization programmes are treated far better than all others at the expense of more valuable programmes that could raise awareness about abuse, rape, democratization, youth unemployment or any of the issues that are more important to everyday Palestinians. (WB3)

The English term, used by Arabic-speaking locals, is 'normalization', which is a dangerous path as illustrated by the following:

Donor [demands] to interact with Israeli local institutions during the course of project implementation with Palestinian team are interpreted by Palestinian local institutions as normalization policy, and that's very risky for them, because they can easily be considered as traitors in the eyes of Palestinian public opinion and become trapped in a public scandal. (WB12)

The stigma is so strong that certain organizations cannot afford to participate in Israeli/ Palestinian meetings as 'any such activity didn't quite fit with our culture as an organization. We are for peacebuilding, but this we could not participate in' (WB2). Organizations that cooperate with Israeli partners follow different strategies by denouncing the Israeli occupation, but emphasizing human relations between Israelis and Palestinians and using a different vocabulary, such as the religious term 'healing' instead of 'normalization' or 'cooperation' (Landau, 2003).

\section{Discussion}

Norms and values, whether they are labelled as western, humanitarian, neoliberal or religious, are part of the foreign 'spiritual and material package' received from external 
donors in Palestine too. If Mauss claimed that there is a magical force included in the given thing, Marcel Hénaff argued that the implication of the donor in the given thing involves 'a transfer of soul and of substantial presence' (Hénaff, 2010: 126):

The entire network of gift exchange consists of the fact that everyone must place something of himself at risk outside of his own place and receive something from others within its own space.

Reflections on and experiences with values conveyed by foreign aid are important for understanding the impact of aid within the Palestinian space and the related consequences. As illustrated by the quoted excerpts, considerable tension exists within Palestinian (civil) society due to the simultaneous existence of factors linking the recipient to the donor (shared organizational culture ensuring cooperation) and factors separating beneficiaries from each other on the one hand, and from their donors on the other (competition for donor money by either making sacrifices or rejecting them in the context of 'national' culture).

Our recently collected empirical data show that western donors preferred working with like-minded recipients not only at macro level (the pro-western PNA/Fatah vs. Hamas in the Gaza Strip), but also at organizational level. This applies to implementing actors on the recipient side too, as they favoured donors with similar vision, cultural or religious norms and values. While western donors usually preferred secular or Palestinian-Christian NGOs as implementing partners, Islamic donors - private persons from the West and private/public donors from the Gulf region - were perceived to give primarily to Islamic charity NGOs. These findings are in line with the literature (Benthall and Bellion-Jourdan, 2009). For the Arab-Islamic aid culture is shaped by 'experiences of marginalization, of being colonized, and of the poor not as a distant sufferer, but as a fellow member of the community'; the differences between western (international) and regional (Islamic) aid cultures were conceptualized in the form of three sets of dichotomies, namely 'universalism vs solidarity, neutrality vs justice, and secularism vs religion' (Petersen, 2015). The more or less fixed partner preferences are confirmed by other cross-cultural studies indicating that the values people endorse might be influenced by group affiliation (nation, religious community) that influences the individual's organizational commitment (Glazer et al., 2004). It apparently applies to cross-cultural, inter-organization cooperation within the context of NGO (development) cooperation. Our respondents cited the shared values and like-mindedness that makes the donor and the recipient feel members of the same 'family'. The intensity, level and nature of religiosity may also explain and strengthen ethical attitudes needed for successful organizational cooperation (Jackson, 2001) between donors and recipients.

As our study shows, loyalty relations and cultural (religious, ideological) borders were perceived to be rarely crossed, even if 'more global' factors, such as business interests, work ethics or universal humanitarian concerns were taken into consideration. The politically motivated aid allocation to local NGOs troubles the relations between various segments of the (otherwise polarized) society by affecting decisions involving conflicts between different loyalty relations regarding the self, the group (nation) or the organization (Jackson, 2001). Leaders of Palestinian Islamic NGOs complained of having been 
ignored unfairly by western donors. They simultaneously criticized the western 'secular' or 'Christian' partner preferences and drew attention to their own 'modern management and communication' skills that would enable them to implement western-financed projects. This latter is confirmed by the literature too. For their projects could be realized only if they got funded - mostly, but not exclusively from within the region - bigger Islamic NGOs also have to apply modern organizational and management tools (Benthall and Bellion-Jourdan, 2009; Petersen, 2015).

The West apparently continues to be a model to which the 'Rest' must somehow adjust. Even if our Palestinian respondents did not believe in the 'supremacy of the West', in order to talk about the relationship between the western donor and the Palestinian (non-)recipient, they had 'to adopt a position' as if they believed it (Hall, 1996: 202), at least in the context of a cross-cultural 'business administration' culture (Steers et al., 2013). Learning this business administration culture from western donors was one of the advantages of cooperation, if not the biggest such advantage. Our respondents, however, used the term 'culture' with alternative meanings highlighting the differences between 'their' culture (implying the experience of being occupied and/or colonized, for example) and that of their donors (prioritizing 'neoliberal' technicized, pragmatic cooperation over solving the problem of Israeli occupation).

The literature on the meanings of culture is vast, offering various definitions both for academic and practical (political) purposes (social and cultural psychology, sociology, cultural sociology, political science, anthology and economics). There are disputed definitions and competing arguments as to whether values, attitudes or behaviour determine the 'culture' of a person or a group. Ann Swidler, as a sociologist, defined it as a loose 'tool-kit of habits, skills and styles' guiding everyday activities and interactions, which is instrumental in providing flexible 'strategies for action' in practical situations (Swidler, 1986). Organization theories in the field of management studies consider culture as a functional solution to the most commonly encountered problems faced in social interactions and situations in a workplace (Trompenaars and HampdenTurner, 1996; Steers et al., 2013). In political science, culture is mostly understood as 'semiotic practices' referring to the processes of meaning-making (Wedeen, 2002) that go beyond the traditional understanding of 'political culture' (Almond and Verba, 1963). For Douglass North (new institutional economics) culture 'consists of intergenerational transfer of norms, values and ideas' (North, 2005: 50). Anthropologists, by debating the meaning of 'culture', ended up fighting in the 'culture and nature' war (Bloch, 2012: 24-78). Drawing a sort of conclusion, Maurice Bloch argued that the two rather complement each other, as mental/cognitive 'cultural models' are not only shaped by 'social and historical processes', but the term 'culture' or 'cultural process' can be understood as identical to 'social, political or historical processes' when one wishes 'to understand the dynamic mechanisms by which information is passed on from one individual to another' (Bloch, 2012: 172-82). It applies to the Middle East too, as the meaning and importance of 'culture' can be neither separated from, nor understood without considering historical and political processes (Nader, 2013). Indeed, cultural and social psychologists claim that cognitive cultural models in individual minds and (shared, social, group) culture are inseparable and mutually shape each other. As such, populations can be seen as culturally diverse because of the 
Table I. Profile of interview participants.

TOTAL

\section{Organizational affiliation}

Locally (registered) NGO (with some western attachment, church included)

Grassroots organization, indigenous, Palestinian initiative (not overtly religious)

Grassroots organization, indigenous, Palestinian initiative (Muslim)

Other (aid-related, but not fundraising; consultancy; religious orientation: n.a.)

\section{Position or title}

Leader (director, general manager, head)

Consultant, coordinator, adviser, fundraising officer

Organizational profile

Humanitarian (relief, charity)

Development (education, youth, sport)

Development (advocacy, democracy-promotion, human rights)

Development (advocacy, gender, equality)

Development (arts, theatre, movie, cultural heritage) 2

Development (agriculture, environment)

Development (family, women)

Other

Respondent's age (group)

26-35

$36-45$

46-55

56-65

Length of experience in the aid industry

less than 3 years

$3-5$ years

5-10 years

over 10 years

Gender

male

female

Level of highest education

university (BA, MA level)

$\mathrm{PhD}$ or similar level

Venue of studies (high school)

Palestine, only

West (Europe or North America)

Other (or we do not know)

Palestine and abroad as well

MENA region (Jordan, Egypt, Gulf, other), but not Palestine 
Table I. (Continued)

TOTAL

West (Europe or North America), but not Palestine 6

Other (or we do not know)

Palestine and abroad as well

Number of donors (past 5 years; 5-10 years), various sizes 22

More than 10

Less than 10

Table 2. List of the interviews.

\begin{tabular}{|c|c|c|c|c|c|}
\hline ID & $\begin{array}{l}\text { Position and field of } \\
\text { activities }\end{array}$ & $\begin{array}{l}\text { Place and date } \\
\text { of the interview }\end{array}$ & ID & Field of activities & $\begin{array}{l}\text { Place and date } \\
\text { of the interview }\end{array}$ \\
\hline WB I & $\begin{array}{l}\text { MGR; Dev.: gender, } \\
\text { equality, human rights }\end{array}$ & $\begin{array}{l}\text { Bethlehem, } \\
6 \text { July, } 2015\end{array}$ & GS I & MGR; Hum. & $\begin{array}{l}\text { Gaza City, } \\
26 \text { June } 2015\end{array}$ \\
\hline WB2 & $\begin{array}{l}\text { MGR; Dev:: } \\
\text { education, youth, } \\
\text { sport }\end{array}$ & $\begin{array}{l}\text { Bethlehem, } \\
\text { I7 July } 2015\end{array}$ & GS2 & $\begin{array}{l}\text { MGR; Dev.: } \\
\text { advocacy, } \\
\text { democracy- } \\
\text { promotion, HR }\end{array}$ & $\begin{array}{l}\text { Gaza City, } \\
3 \text { Aug. } 2015\end{array}$ \\
\hline WB3 & $\begin{array}{l}\text { MGR; Dev.: } \\
\text { education, youth, } \\
\text { sport }\end{array}$ & $\begin{array}{l}\text { Hebron, } \\
28 \text { July } 2015\end{array}$ & GS3 & $\begin{array}{l}\text { MGR; Dev.: } \\
\text { gender, equality, } \\
\text { human rights }\end{array}$ & $\begin{array}{l}\text { Khan Younis } \\
\text { City, } \\
5 \text { Aug. } 2015\end{array}$ \\
\hline WB4 & $\begin{array}{l}\text { MGR; Dev.: advocacy, } \\
\text { democracy- } \\
\text { promotion, HR }\end{array}$ & $\begin{array}{l}\text { Bethlehem, } \\
30 \text { July } 2015\end{array}$ & GS4 & $\begin{array}{l}\text { MGR; Dev.: } \\
\text { agriculture, } \\
\text { environment }\end{array}$ & $\begin{array}{l}\text { Khan Younis } \\
\text { City, } \\
7 \text { Aug. } 2015\end{array}$ \\
\hline WB5 & $\begin{array}{l}\text { MGR; Dev.: gender, } \\
\text { equality, human rights }\end{array}$ & $\begin{array}{l}\text { Nablus, } \\
6 \text { Aug. } 2015\end{array}$ & GS5 & $\begin{array}{l}\text { MGR; Dev.: } \\
\text { agriculture, } \\
\text { environment }\end{array}$ & $\begin{array}{l}\text { Gaza City, } \\
10 \text { Aug. } 2015\end{array}$ \\
\hline WB6 & $\begin{array}{l}\text { MGR; Dev.: gender, } \\
\text { equality, HR }\end{array}$ & $\begin{array}{l}\text { Nablus, } \\
6 \text { Aug. } 2015\end{array}$ & GS6 & $\begin{array}{l}\text { MGR; Hum. and } \\
\text { Dev. }\end{array}$ & $\begin{array}{l}\text { Gaza City, } \\
\text { II Aug. } 2015\end{array}$ \\
\hline WB7 & $\begin{array}{l}\text { PC; Dev.: gender, } \\
\text { equality, human rights }\end{array}$ & $\begin{array}{l}\text { Ramallah, } \\
10 \text { Aug. } 2015\end{array}$ & GS7 & $\begin{array}{l}\text { MGR; Dev.: } \\
\text { education, } \\
\text { youth, sport }\end{array}$ & $\begin{array}{l}\text { Gaza City, } \\
16 \text { Aug. } 2015\end{array}$ \\
\hline WB8 & $\begin{array}{l}\text { MGR; Dev.: institution } \\
\text { building }\end{array}$ & $\begin{array}{l}\text { Ramallah, } \\
10 \text { Aug. } 2015\end{array}$ & GS8 & $\begin{array}{l}\text { PC; Dev.: family, } \\
\text { women }\end{array}$ & $\begin{array}{l}\text { Gaza City, } \\
\text { I Sept. } 2015\end{array}$ \\
\hline WB9 & PC; Hum. and Dev. & $\begin{array}{l}\text { Ramallah, } \\
\text { I Sept. } 2015\end{array}$ & GS9 & MGR; Hum. & $\begin{array}{l}\text { Beit Lahia, } \\
13 \text { Sept. } 2015\end{array}$ \\
\hline WBIO & MGR: Hum. and Dev. & $\begin{array}{l}\text { Ramallah, } \\
\text { I Sept. 2015 }\end{array}$ & GSIO & MGR; Hum. & $\begin{array}{l}\text { Jabalia Camp, } \\
21 \text { Sept. } 2015\end{array}$ \\
\hline WBII & $\begin{array}{l}\text { MGR; Dev.: cultural } \\
\text { heritage }\end{array}$ & $\begin{array}{l}\text { Ramallah, } \\
\text { Sept. } 2015 \\
\text { (email) }\end{array}$ & - & & \\
\hline WBI 2 & FO; Hum. & $\begin{array}{l}\text { Bethlehem, } \\
\text { Oct. } 2015 \\
\text { (email) }\end{array}$ & - & & \\
\hline
\end{tabular}

MGR: managerial position (director, managing director, general manager, executive manager, etc.); PC: project coordinator; FO: fundraising officer; HR: human rights; Dev.: development; Hum.: humanitarian and relief activities. 
'inherited responsiveness and flexibility to social context' (Fiske and Taylor, 2013: 26). To sum up, adaptation to the surrounding social environment is of crucial importance in understanding the meaning of culture, the related 'cultural or mental models' guiding individual actions, the role of solidarity, and the practice and consequences of contemporary international gift-giving. It applies to aid recipient NGOs to the extent to which they are simultaneously part(icipants) of the 'Palestinian culture' and supposed to have a shared culture with external donors.

The findings highlight the importance of 'cultural forces' and aspirations behind the gift (aid) object itself. The 'new spirit of interventionism' in emergency and humanitarian projects 'goes beyond relief' by aspiring 'to transform the economic and political structures' for the sake of vulnerable others (Chouliaraki, 2010: 9). This is even more the case for development projects in Palestine. Maurice Bloch posed the question of what exposure to 'foreign material' means by recalling an old experiment. While he applied this expression to contemporary foreign media (television, soap opera), his argument bears a broader significance with reference to development/humanitarian cooperation. As claimed, the effect of 'foreign' inputs - the 'spiritual essence' of the gift in anthropology theories, the norms and values conveyed by external grants in our contemporary world - may not be so straightforward as is assumed (by development specialists or aid officers) since people with a totally different cultural background need a considerable amount of time to absorb the conveyed ideas and concepts that are alien to the 'cultural' or 'mental' models individuals have in mind (Bloch, 2012: 75). Discussing the power of institutions, Douglass North also argued that '[foreign] ideas too far from the norms embodied in our culture cannot easily be incorporated into our culture' (North, 2005: 27). A question is how these external norms and values are related to realities such as - in the Palestinian case - the Israeli occupation, oppression, denial of self-determination and related perceptions. While foreign aid policies, programmes and projects are usually built on the assumption that people are rational decision makers, research shows that this is not exactly true. Indeed, some of our respondents honoured the 'spiritual' part of the contemporary gift, while others found accepting western aid shameful or counterproductive simultaneously. As argued by Bloch and North, among others, social norms and mental models have a more profound effect on our thinking and behaviour than is assumed.

Labels such as 'neocolonial' or 'neoliberal' have been used in the Palestinian context (Nakhleh, 2004, 2013; Tabar et al., 2015; Tartir, 2014) for many years to describe the frustration over the provocative question, formulated in a different context though, 'What can your nation do for you that a good credit card cannot?' (Hannerz, 1996: 88). The bitter accusation formulated as the 'national sellout of a homeland' (Nakhleh, 2013) symbolizes the tensions between the priorities of foreign grants (alleviate the sufferings of Palestinians, support 'apolitical' development projects, cooperate with Israel without asking sensitive questions) and the real Palestinian demands such as national self-determination and ending the occupation. Hannerz's question, combined with the lack of an adequate/convincing reply in the Palestinian case, cannot be understood without acknowledging the donors' stubborn insistence on 'supporting the peace process' by massive foreign donations at the expense of true peace. 


\section{Conclusion}

Western, especially European donors have promoted the idea that true peace between Israel and the Palestinians/Arabs is possible based on rational interests for decades. However, the de-politicization and 'neoliberal technicization' of development cooperation in Palestine, humanitarian assistance included (Nakhleh, 2013; Tabar et al., 2015; Tartir, 2014), shows that foreign donors and aid fail to tackle the real problems (the Israeli occupation, lack of self-determination, lack of progress in the peace process). Lilie Chouliaraki drew attention to the long-term danger in 'removing the moral question of "why" from humanitarian communication' - from humanitarian and development actions, activities and discourse in general - arguing that it perpetuates 'a political culture of [western] communitarian narcissism' (Chouliaraki, 2010: 20). While recipients cannot but be grateful for (ironic) solidarity and generosity, adaptation to culturally diverse environments existing parallel to each other leads to serious tensions.

The article aimed to explore the role of culture and shared values in donor-recipient relations in the Palestinian context. Our data showed that contemporary gifts are given with a 'burden attached' at the macro-political level, even if positive impacts were reported at micro/NGO level. These findings are in line with earlier research exploring the motives, intentions, interests and tendencies of recipient participation in other parts of the world (Anderson, 2012; Contu and Girei, 2014; Fechter, 2014; Khan et al., 2011). These studies reveal that civil society actors find themselves somehow 'squeezed' between the demands of their own, indigenous culture ('history and society') and the organizational and business-oriented cultures influenced and shaped by external actors (Israel and the donors). As 'passive' recipients are usually unable to return gestures (foreign aid) in financial terms, they are 'expected to offer the only thing they had in exchange for foreign gifts: control over some part of their lives' (Blau, 1964 cited by Camenisch, 1981: 4).

Western donors usually 'control' the recipients by emphasizing partnership (Contu and Girei, 2014) and by demanding transparency and accountability in name of aid effectiveness (Escobar, 2011; Furia, 2015). Critiques regarding western or 'neoliberal' support emphasize 'depoliticizing the political', that is, the 'technicization' of the Palestinian 'problem' (Lentin, 2008; Nakhleh, 2013; Tabar et al., 2015; Tartir, 2014). International cooperation at the level of NGOs, the adaptation of 'modern management and communication methods' from western donors, coupled with a culture advocating IsraeliPalestinian 'normalization' and marginalizing certain Palestinian recipients have become both a means and a symbol of globalization, neo-colonization or neoliberalism. The 'spiritual essence' embodied in contemporary gifts might turn foreign aid into a 'poisonous gift' that needs to be tasted to understand its impact on national sovereignty. The price of the benefits gained at an individual and organizational level are paid for by sacrificing group-level norms and values.

\section{Funding}

The author(s) disclosed receipt of the following financial support for the research, authorship, and/ or publication of this article: This research was supported by the European Union under a Marie Curie IEF grant (AIDINMENA project, 2013-2015 [2016], grant number PIEF-GA-2012-327088; 
host institute: Fafo Research Foundation, Oslo) and complemented by the Research Council of Norway (NFR).

\section{Notes}

1. It is beyond the scope of this article to discuss here whether foreign aid reflects (real, true or ironic) solidarity or whether it is just a foreign policy tool. The term 'foreign aid' covers development and humanitarian assistance (grants and concessional loans) alike, but in the Palestinian context under discussion, mostly grants are provided. Humanitarian (emergency) assistance is part of the official development assistance (ODA) in international statistics. While the terms 'donor' and 'recipient' usually refer to the countries concerned, they can also be applied to NGOs, depending on the context.

2. Bloch discusses the meaning of culture and 'cultural models' in depth, noting that he prefers to use 'social and historical processes' (instead of culture) as explanatory factor (Bloch, 2012: 172-85).

3. And not attaining lofty objectives (declared in official foreign/development policy documents) or being effective (as is assumed by many development economists participating in the aid effectiveness debate).

4. For facts about Palestinian civil society see the International Center for Not-for-profit Law (ICNL): http://www.icnl.org/research/monitor/palestine.html.

5. Not all non-state beneficiaries actively promote change. Carapico (2014) provides a good overview on the differences between NGOs, GONGOs (government organized non-governmental organizations), DONGOs (donor-organized non-governmental organizations), etc. in the region (see in particular Chapter 4, 'Denationalizing civic activism', Carapica, 2014: 153-7). On the dilemmas NGOs face in the region, see Merip 214 (vol. 30, Spring 2000): http://www.merip.org/mer/mer214/.

6. Tables containing the respondents' profiles and details of the interviews can be found at the end of the document, and a detailed description of the data collection and analysis can be found in two sister-articles accepted for publication (on how return gifts can be conceptualized see Paragi (forthcoming); on the role of power in contemporary gift relations see Paragi, 2016c). I thank my Palestinian colleagues and those who participated in the interviews for sharing their thoughts with us during the data collection phase. Conclusions drawn are my sole responsibility.

7. The coding table and excerpts/quotations can be obtained from the author.

8. This element will not be detailed in this paper.

9. On Egypt see Selim, The International Dimensions (2015: 86-7).

10. Big Islamic organizations (Islamic Relief, Islamic Development Bank) receive aid from official western donors and institutions, not only from charitable individuals living in western countries. For further information, see the annual reports on their websites.

11. Paragi (forthcoming), also discusses these results (perceptions on shame and stigma), among others, conceptualizing 'stories of sufferings/misfortune' as return gifts.

\section{References}

Almond GA and Verba S (1963) The Civic Culture: Political Attitudes and Democracy in Five Nations. Princeton, NJ: Princeton University Press.

Anderson MB (2012) Time to Listen: Hearing People on the Receiving End of International Aid. Cambridge, MA: CDA Collaborative Learning Projects

Anheier H (2014) Nonprofit Organizations: Theory, Management, Policy. New York: Routledge. Baldwin DA (1985) Economic Statecraft. Princeton, NJ: Princeton University Press. 
Baldwin DA (1998) Exchange theory and international relations. International Negotiation 3: $139-149$.

Benthall J and Bellion-Jourdan J (2009) The Charitable Crescent: Politics of Aid in the Muslim World. London: I.B. Tauris.

Bloch M (2012) Anthropology and the Cognitive Challenge. Cambridge: Cambridge University Press.

Bouris D (2014) The European Union and Occupied Palestinian Territories: State-building without a State. London: Routledge.

Brynen R (2000) A Very Political Economy: Peacebuilding and Foreign Aid in the West Bank and Gaza. Washington, DC: USIP.

Camenisch PF (1981) Gift and gratitude in ethics. Journal of Religious Ethics 9(1): 1-34.

Carapico S (2014) Political Aid and Arab Activism: Democracy Promotion, Justice and Representation. New York: Cambridge University Press.

Chouliaraki L (2010) Post-humanitarianism: humanitarian communication beyond a politics of pity. International Journal of Cultural Studies 13(2): 107-126.

Chouliaraki L (2013) The Ironic Spectator: Solidarity in the Age of Post-humanitarianism. Cambridge: Polity.

Contu A and Girei E (2014) NGOs management and the value of 'partnerships' for equality in international development: what's in a name? Human Relations 67(2): 205-232.

Corbin JA and Strauss A (2008) Basics of Qualitative Research. Thousand Oaks, CA: Sage.

Dana T (2013) Palestinian Society: What Went Wrong? Policy Brief. Ramallah: Al Shabaka.

Duffield M (2001) Global Governance and the New Wars: The Merging of Development and Security. London: Zed Books.

Duffield M (2007) Development, Security and Unending War. London: Zed.

Escobar A (2011) Encountering Development: The Making and Unmaking of the Third World. Princeton, NJ: Princeton University Press.

Eyben R (2006) The power of the gift and the new aid modalities. IDS Bulletin 37(6): 88-98.

Fechter A (2014) The Personal and the Professional in Aid Work. London: Routledge.

Fiske ST and Taylor SE (ed.) (2013) Social Cognition: From Brains to Culture. New York: Sage.

Furia A (2015) The Foreign Aid Regime: Gift-giving, States and Global Dis/Order. London: Palgrave Pilot.

Glaser BG and Strauss AL (1967) The Discovery of Grounded Theory: Strategies for Qualitative Research. Chicago: Aldine.

Glazer S et al. (2004) A study of the relationship between organizational commitment and human values in four countries. Human Relations 57(3): 323-345.

Godbout JT and Caille A (1998) The World of the Gift. Montreal: McGill-Queen's University Press.

Hall S (1996) The West and the rest: discourse and power. In:Hall S, Held D, Hubert D and Thompson K (eds) Modernity: An Introduction to Modern Societies. Malden, MA: Blackwell.

Hannerz U (1996) Transnational Connections: Culture, People, Places. London: Routledge.

Hardy C, Palmer I and Phillips N (2000) Discourse as a strategic resource. Human Relations 53(9): $1227-1248$.

Hattori T (2001) Reconceptualizing foreign aid. Review of International Political Economy 8(4): 633-660.

Hattori T (2006) A critical naturalist approach to power and hegemony, analyzing giving practices. In: Haugaard M and Lentner HH (eds) Hegemony and Power: Consensus and Coercion in Contemporary Politics. Oxford: Lexington.

Hénaff M (2010) The Price of Truth: Gift, Money and Philosophy. Stanford, CA: Stanford University Press. 
Hofstede G et al. (2005) Cultures and Organizations: Software of the Mind. New York: McGrawHill Professional.

Jackson T (2001) Cultural values and management ethics: a 10-nation study. Human Relations 54(10): 1267-1302.

Kapoor I (2008) The Postcolonial Politics of Development. London: Routledge.

Keating M (ed.) (2005) Aid, Diplomacy and Facts on the Ground: The Case of Palestine. London: RIIA.

Khan FR, Westwood R and Boje DM (2011) 'I feel like a foreign agent': NGOs and corporate social responsibility interventions into Third World child labor. Human Relations 63(9): 1417-1438.

Komter AE (2005) Social Solidarity and the Gift: Cambridge, Cambridge University Press.

Kothari U (2006) From colonialism to development: reflections of former colonial officers. Commonwealth and Comparative Politics 44(1): 118-136.

Landau Y (2003) Healing the Holy Land: Interreligious Peacebuilding in Israel/Palestine. Peaceworks 51. Washington: USIP.

Lazarus N and Gawerc M (2015) The unintended impacts of 'material support': US anti-terrorism regulations and Israeli/Palestinian peacebuilding. Journal of Peacebuilding and Development 10(2): 68-73.

Le More A (2008) International Assistance to the Palestinians after Oslo. Political Quilt, Wasted Money. London: Routledge.

Lentin R (2008) Thinking Palestine. London: Zed.

Mauss M (2000 [1925]) The Gift: Forms and Functions of Exchange in Archaic Societies. London: Routledge.

Murad N (2014) Donor Complicity in Israel's Violations of Palestinian Rights. Policy Brief. Ramallah: Al-Shabaka.

Nabulsi K (2005) The state-building project: what went wrong? In Keating M et al. (eds) Aid, Diplomacy and Facts on the Ground. London: RIIA, pp. 117-128.

Nader L (2013) Culture and Dignity: Dialogues between the Middle East and the West. WileyBlackwell.

Nakhleh K (2004) The Myth of Palestinian Development: Political Aid and Sustainable Deceit. Jerusalem: PASSIA.

Nakhleh K (2013) Globalized Palestine: The National Sell-out of a Homeland. Trenton, NJ: Red Sea Press.

North D (2005) Understanding the Process of Economic Change. Princeton, NJ: Princeton University Press.

Paragi B (2015) Eastern and western perceptions on EU aid in light of the Arab Spring. Democracy and Security 11(1): 60-82.

Paragi B (2016a) Divide et impera? Foreign aid interventions in the Middle East and North Africa region. Journal of Intervention And Statebuilding 10(2): 200-221.

Paragi B (2016b) Foreign aid, international social exchange and reciprocity in the Middle East. In: El-Anis I et al. (eds) Regional Integration and National Disintegration in the Post-Arab Spring Middle East. Newcastle upon Tyne: Cambridge Scholars, pp. 72-97.

Paragi B (2016c) Hegemonic solidarity? NGO perceptions on power, solidarity, and cooperation with their donors. Alternatives 41(2), published online, December 2016.

Paragi B (forthcoming) Contemporary gifts: solidarity, compassion, equality, sacrifice and reciprocity from the perspective of NGOs. Current Anthropology (accepted for publication, May 2016).

Petersen MJ (2016) For Humanity or for the Umma? Aid and Islam in Transnational Muslim NGOs. London: Hurst. 
Pyyhtinen O (2014) The Gift and Its Paradoxes, Beyond Mauss. Farnham: Ashgate.

Razack SH (2007) Stealing the pain of others: reflections on Canadian humanitarian responses. Review of Education, Pedagogy and Cultural Studies 29(4): 375-394.

Sahlins M (1972) Stone Age Economics. Chicago: Aldine-Atherton.

Said N (2005) Palestinian perceptions of international assistance. In: Keating M et al. (eds) Aid, Diplomacy and Facts on the Ground. London: RIIA, pp. 99-107.

Salamon J (ed.) (2015) Solidarity beyond Borders: Ethics in a Globalising World. London: Bloomsbury Academic.

Selim GM (2015). The International Dimensions of Democratization in Egypt: The Limits of Externally Induced Change. Berlin: Springer.

Smillie I (1995) The Alms Bazaar: Altruism under Fire. Non-profit Organisations and International Development. London: Intermediate Technology.

Springer J (2015) Assessing donor-driven reforms in the Palestinian Authority: building the state or sustaining the status quo. Journal of Peacebuilding and Development 10(2): 1-19.

Steers RM et al. (2013) Management across Cultures: Developing Global Competencies. Cambridge: Cambridge University Press.

Stirrat RL and Henkel H (1997) The development gift: the problem of reciprocity in the NGO world. Annals of the American Academy of Political and Social Science 55(4): 66-80.

Swidler A (1986) Culture in action: symbols and strategies. American Sociological Review 51(April): 273-286.

Tabar L et al. (2015) Critical Readings of Development under Colonialism: Towards a Political Economy for Liberation in the Occupied Palestinian Territories. Ramallah: Bir Zeit University CDS and Rosa Luxemburg Foundation.

Taghdisi-Rad S (2011) The Political Economy of Aid in Palestine, Relief from Conflict or Development Delayed? London: Routledge.

Tartir A (2014) Criminalising Resistance, Entrenching Neoliberalism: The Fayyadist Paradigm in Occupied Palestine. PhD thesis, London, LSE.

Trompenaars F and Hampden-Turner C (1996) Riding the Waves of Culture: Understanding Diversity in Global Business. New York: McGraw-Hill Education.

Uphoff N (1993) Grassroots organizations and NGOs in rural development. World Development 21(4): 607-622.

Wedeen L (2002) Conceptualizing culture: possibilities for political science. American Political Science Review 96(4): 713-728.

Wilde L (2013) Global Solidarity. Edinburgh: Edinburgh University Press.

Wildeman J and Tartir A (2014) Unwilling to change, determined to fail: donor aid in Occupied Palestine in the aftermath of the Arab uprisings. Mediterranean Politics 19(3): 431-449.

\section{Author biography}

Beata Paragi is an assistant professor at Corvinus University of Budapest and a former Marie Curie fellow at Fafo Research Foundation, Oslo. A monograph containing results of her recent research project is under review with I.B. Tauris. Having graduated as an economist with a major in international relations her research interest covers the Middle East, East-West relations, economic and gift theories, and related writings in anthropology and philosophy. 